\title{
Potensi Ekstrak Etanol Biji Jintan Hitam (Nigella sativa) untuk Pengendalian Bakteri Vibrio harveyi Penyebab Penyakit pada Udang Vaname (Litopenaeus vannamei)
}

\section{The Potency of Ethanol Extracts of Black Cumin (Nigella sativa) to Control Vibrio harveyi Causing Disease in Vannamei Shrimp (Litopenaeus vannamei)}

\author{
Linianti $^{1)}$, Indriyani $\mathrm{Nur}^{\left.2^{*}\right)}$, Maulidiyah ${ }^{3)}$, dan Yusnaini ${ }^{2)}$ \\ ${ }^{1)}$ Mahasiswa Program Studi Magister Ilmu Perikanan Pascasarjana Univ. Halu Oleo \\ ${ }^{2)}$ Fak Perikanan dan Ilmu Kelautan Univ. Halu Oleo, ${ }^{3)}$ Fak Matematika dan Ilmu Pengetahuan Alam Univ Haluo Oleo \\ Corresponding author ${ }^{*}$ : indri_noer@yahoo.com; liniantiridho@yahoo.co.id,
}

\begin{abstract}
Research on the potential of the ethanol extract of black cumin seeds (EEBCS) have been conducted through in vitro and in vivo test. This study aimed to analyze the use of the EEBCS to inhibit the growth of bacteria Vibrio harveyi, and the ability of EEBCS as immunostimulant on white bacteria-infected shrimp $V$. harveyi. Testing of EEBCS to inhibit bacterial growth $V$. harveyi performed in vitro at concentrations of 2500,5000 , and 7500 $\mathrm{ppm}$. The results obtained in vitro test showed that EEBCS can inhibit the growth of bacteria $V$. harveyi in all concentrations.
\end{abstract}

Keywords: Black cumin seeds, Vibrio harveyi, in vitro, Litopenaeus vannamei.

\section{ABSTRAK}

Penelitian ini bertujuan menganalisis pemanfaatan ekstrak etanol biji jintan hitam untuk pencegahan bakteri Vibrio harveyi penyebab penyakit pada udang vaname(Litopenaeus vannamei) sebagai penghambat tumbuh bakteri $V$. harveyi secara in vitro. Hasil yang diperoleh pada uji in vitro menunukkan bahwa ekstrak etanol biji jintan hitam mampu menghambat pertumbuhan bakteri $V$. harveyi dan bersifat antibakterial terutama pada konsentrasi 2500 , $5000,7500 \mathrm{ppm}$.

Kata Kunci : ektrak jintan hitam, Vibrio harveyi, in vitro, udang vaname

DOI: http://dx.doi.org/10.33772/jspi.v1n1.xxxx

\section{PENDAHULUAN}

Keunggulan udang vaname dibudidayakan yaitu pemeliharaan relatif singkat dapat mencapai ukuran konsumsi, mempunyai toleransi terhadap penurunan salinitas, relatif tahan penyakit, produktivitasnya tinggi, waktu pemeliharaan relatif singkat (90 hari), relatif tinggi kelangsungan hidup dan permintaan pasar terus meningkat (Luksrejo, 2008).

Budidaya udang vaname berkembang, namun berbagai kendala timbul seiring perkembangan budidaya pada tahap pembenihan maupun tahap pembesaran, seperti serangan penyakit, menyebabkan terjadinya kematian. Penyakit pada budidaya udang vaname seperti infeksi bakteri, didominasi oleh bakteri jenis Vibrio harveyi dan serangannya dapat menyebar dalam waktu sangat cepat (Sukenda et al., 2005). Bakteri ini merupakan genus Vibrio yang bersifat patogenik menyebabkan kematian sebesar 1880\% (Hoa et al., 2006).

Upaya pencegahan penyakit infeksi bakteri dapat dilakukan dengan pemberian imunostimulan (Ridlo dan Rini, 2009). Imunostimulan tidak meninggalkan residu dan aman untuk lingkungan 
(Marentek dan Manoppo, 2013). Jintan hitam (Nigella sativa) adalah tanaman yang dapat dijadikan sebagai bahan imunostimulan (Dorucu et al., 2009; Shewita et al., 2011). Jintan hitam memiliki kemampuan antivirus (Zaher et al., 2008); antifungi (Suthar, 2010), antibakteri (Hosseinzadeh et al., 2007; Hannan et al., 2008; Dorucu et al., 2009) dan antiparasit (Ayaz et al., 2007). Ekstrak jintan hitam juga terbukti mampu meningkatkan sistem imun nonspesifik dan spesifik (Balai Penelitian Obat dan Makanan, 2013).

Tujuan penelitian adalah mengetahui pengaruh ekstrak biji jintan hitam terhadap immunostimulan dan pencegahan bakteri $V$. harveyi melalui pemberian ekstrak biji jintan hitam pada pakan untuk menghambat pertumbuhan bakteri $V$. harveyi secara in vitro pada udang vaname yang terinfeksi bakteri $V$. harveyi

\section{METODE PENELITIAN}

Penelitian ini dilaksanakan pada bulan Maret sampai Juli tahun 2016 di Laboratorium Kimia Farmasi dan Jurusan Perikanan Fakultas Perikanan dan Ilmu Kelautan Universitas Halu Oleo Kendari.

Udang uji yaitu udang vaname yang berukuran berat $\pm 7 \mathrm{~g}$ sebanyak 150 ekor yang berasal dari tambak. Udang uji diberi pakan pelet komersil kandungan protein $30 \%$, lemak 5\%, serat kasar 5\%, abu $13 \%$ dan kadar air $11 \%$. Pakan dicampur dengan ekstrak biji jintan hitam dengan cara disemprotkan sebanyak dosis yang didapat dari dosis yang terbaik pada uji in vitro dan sebagai perekat ditambahkan putih telur sebanyak 2\% (Zubaidah et al., 2014). Pemberian pakan dilakukan sebanyak 4 kali sehari, yaitu pukul 07.00, 11.00, 15.00 dan 19.00. Pengeluaran kotoran-kotoran yang mengendap di dasar aquarium dengan cara airnya disifon setiap hari (pagi dan sore) sebanyak $10 \%$ air pada setiap akuarium, sebelum diberi pakan.

\section{Pembuatan Ekstrak Etanol Biji Jintan Hitam (Harborne, 1987)}

Biji jintan hitam dicuci bersih dengan air, selanjutnya dikeringkan di udara terbuka (kering udara) tanpa terkena cahaya matahari langsung untuk menghindari kerusakan bahan aktif. Selanjutnya biji jintan dijadikan serbuk halus dengan cara dihaluskan dan diayak dengan saringan halus sehingga diperoleh simplisia.
Ekstraksi yang dilakukan yaitu, biji jintan hitam sebanyak $2900 \mathrm{~g}$ dimaserasi menggunakan pelarut etanol 96\% selama 72 jam, lalu difiltrasi dengan corong Buchner untuk memperoleh filtrat. Maserasi dilakukan sebanyak 3 kali, filtrat yang diperoleh kemudian disatukan dan dipekatkan dengan menggunakan rotary evaporator vacum pada suhu maksimal $50{ }^{0} \mathrm{C}$ hingga pelarut etanol menguap dan terbentuk ekstrak kental hitam, kemudian dituang ke dalam botol vial gelap, selanjutnya ditimbang total ekstrak yang diperoleh sebanyak 438 gram.

\section{Uji Fitokimia Ekstrak Etanol Biji Jintan Hitam}

Uji fitokimia untuk pemeriksaan kandungan metabolit sekunder yang dilakukan merupakan uji skrining kualitatif yang digunakan untuk mengetahui ada atau tidaknya (+/-) kandungan senyawa metabolit sekunder pada ekstrak murni biji jintan hitam. Pemeriksaan kandungan metabolit sekunder yang dilakukan, terdiri dari uji alkaloid, uji terpenoid, uji flavonoid, uji saponin dan uji tanin (Kristianti, et al., 2008).

\section{Uji in vitro}

Uji in vitro untuk mengatati daya hambat bakteri dari ekstrak biji jintan hitam dan menentukan dosis terbaik sebagai penghambat pertumbuhan bakteri $V$. harveyi. Dosis terbaik yang didapatkan dari uji in vitro oleh Grandiosa (2010) adalah 5000 ppm. Penelitian menggunakan dosis berbeda yaitu 2500 ppm, 5000 ppm, 7500 ppm dan digunakan ke uji in vivo. Uji zona daya hambat dilakukan untuk mengetahui kemampuan biji jintan hitam sebagai pencegahan dengan menggunakan kertas cakram diameter $5 \mathrm{~mm}$ dibuat dari kertas saring Whatman No. 42 dan direndam dalam larutan ekstrak biji jintan hitam pada konsentrasi 2500 ppm, 5000 ppm, 7500 ppm, kontrol (-), kontrol (+) selama 24 jam.

\section{Uji Aktivitas Hambat Tumbuh Bakteri (Lay, 1994; Trianto dkk., 2004)}

Prosedur ini menggunakan metode Kirby-Bauer, ditunjukan dengan adanya zona bebas/hambat di sekitar kertas cakram. Prosedur kerja : media (TCBS) disiapkan pada cawan petri, kemudian isolat $V$. harveyi sebanyak $10 \mathrm{ml}$ kepadatan $10^{6} \mathrm{CFU} / \mathrm{ml}$ diambil dari biakan murni yang telah diencerkan dalam larutan fisologis Natrium Klorida $(\mathrm{NaCl}) 9 \mathrm{ml}$ yang berfungsi sebagai pemisah bakteri. Bakteri kemudian disebar pada permukaan agar secara merata 
menggunakan batang L glass. Kertas saring steril yang sebelumnya telah dibentuk bulat kecil yang masing-masing berdiameter $5 \mathrm{~mm}$ dicelupkan ke dalam larutan uji, selanjutnya paper disc diletakan pada permukaan media inokulasi dengan bantuan pinset. Bakteri diinkubasi dalam inkubator dengan suhu konstan $37{ }^{0} \mathrm{C}$, lalu diamati setelah 24 jam. Diameter zona hambat lalu diukur dengan menggunakan jangka sorong.

\section{Perlakuan dan Rancangan Penelitian}

Dosis yang digunakan ekstrak jintan hitam setiap perlakuan adalah dosis terbaik dari hasil uji in vitro. Rancangan penelitian menggunakan Rancangan Acak Lengkap dengan 5 perlakuan dan 3 ulangan.

Perlakuan K- : PBS (kontrol negatif).

Perlakuan $\mathrm{K}+\quad$ : $\quad$ Kloramfenikol(kontrol positif)

Perlakuan A : Konsentrasi ekstrak etanol biji jintan hitam $2500 \mathrm{ppm}$.

Perlakuan B : Konsentrasi ekstrak etanol biji jintan hitam 5000 ppm.

Perlakuan C : Konsentrasi ekstrak biji jintan hitam 7500 ppm.

Data hasil uji in vitro dianalisis menggunakan uji ANOVA, kemudian jika hasilnya berbeda nyata dilakukan uji lanjut Beda Nyata Terkecil (BNT) pada selang kepercayaan $95 \%$.

\section{HASIL DAN PEMBAHASAN}

Hasil

Hasil uji fitokimia terhadap ekstrak etanol biji jintan hitam yang dilakukan dengan metode Brontrager disajikan pada Tabel 1.

Tabel 1. Uji fitokimia ekstrak etanol biji jintan hitam

\begin{tabular}{llc}
\hline No & Uji senyawa & Hasil analisis \\
\hline 1 & Alkaloid & ++ \\
2 & Tanin/Polifenol & ++ \\
3 & Quinon & ++ \\
4 & Flavonoid & + \\
5 & Terpenoid & + \\
6 & Saponin & -
\end{tabular}

*Ket : Kuat (++), Lemah (+), Tidak ada (-)

Uji in vitro ekstrak biji jintan hitam terhadap bakteri $V$. harveyi disajikan pada pada Tabel 2.
Tabel 2. Uji in vitro ekstrak etanol biji jintan hitam terhadap bakteri $V$. harveyi

\begin{tabular}{lccccc}
\hline \multirow{1}{*}{$\begin{array}{c}\text { Perlakuan } \\
\text { (ppm) }\end{array}$} & \multicolumn{4}{c}{$\begin{array}{c}\text { Diameter Zona } \\
\text { Hambat }(\mathrm{cm})\end{array}$} & $\begin{array}{c}\text { Rata-Rata } \\
(\mathrm{cm})\end{array}$ \\
\cline { 2 - 5 } & \multicolumn{4}{c}{ Ulangan } & \\
\cline { 2 - 5 } & I & II & III & IV & \\
\hline Akuades & 0 & 0 & 0 & 0 & 0,00 \\
Kloramfenikol & 4,0 & 2,3 & 3,1 & 3,8 & 3,30 \\
$2500 \mathrm{ppm}$ & 1,6 & 1,4 & 1,7 & 1,3 & $1,50^{\mathrm{a}}$ \\
$5000 \mathrm{ppm}$ & 1,7 & 1,9 & 1,7 & 1,8 & $1,77^{\mathrm{b}}$ \\
$7500 \mathrm{ppm}$ & 1,9 & 2,1 & 2,4 & 2,1 & $2,12^{\mathrm{c}}$ \\
\hline
\end{tabular}

*Ket : Ukuran paper disc 0,7 cm, (-) akuades, (+) kloramfenikol

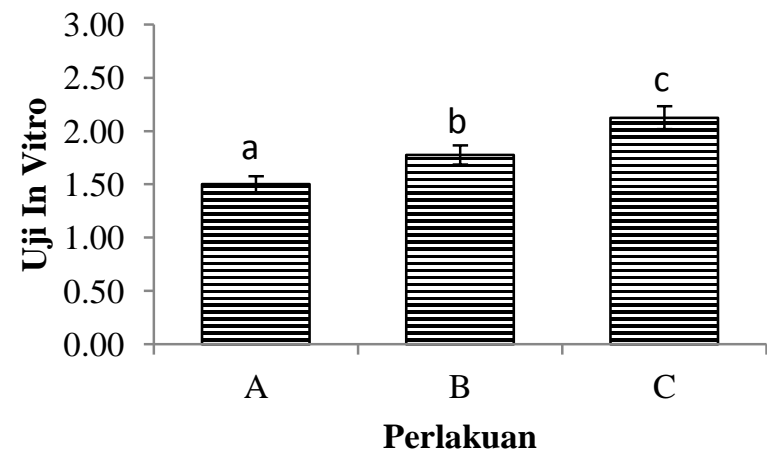

Gambar 1. Uji zona daya hambat bakteri $V$. harveyi (Uji in vitro) Perlakuan A dengan konsentrasi 2500 ppm, Perlakuan B dengan konsentrasi 5000 ppm, Perlakuan C dengan konsentrasi 7500 ppm (Ket: Masing-masing perlakuan menunjukan berbeda nyata).

\section{Pembahasan}

Uji in vitro ekstrak etanol biji jintan hitam terhadap bakteri $V$. harveyi menunjukan bahwa ekstrak tersebut memiliki aktivitas sebagai antibakterisidal. Aktivitas antibakterisidal tersebut ditunjukan dengan terbentuknya zona daya hambat di sekitar paper disc (Tabel 2). Ekstrak etanol biji jintan hitam mampu menghambat pertumbuhan bakteri $V$. harveyi, salah-satu penyebab penyakit pada udang.

Pada Tabel 2, rata-rata diameter zona hambat berkisar antara $0-4,0 \mathrm{~cm}$. Kandungan biji jintan hitam adalah minyak volatil, terdiri dari timokuinon, timohidrokuinon, ditimokuinon, timol, dan tannin terbukti mampu menghambat pertumbuhan bakteri dan fungi (Mashhadian dan Rakhshandeh, 2005; AlJabre et al., 2003). Aktivitas antibakterisidal dari ekstrak etanol biji jintan hitam tidak lebih besar dibandingkan dengan kontrol positifnya, yaitu 
antibiotik kloramfenikol sebesar $30 \mathrm{ppm}$. Hal tersebut terjadi karena kloramfenikol merupakan senyawa murni. Mekanisme kerja pada senyawa yang terkandung pada bahan alami yaitu obat yang akan digunakan untuk pencegahan mikroba penyebab infeksi harus memiliki sifat toksisitas yang tinggi. Antibakteri menghambat sintetis dinding sel bakteri mempunyai lapisan luar sel yang kaku, yaitu dinding sel. Dinding sel mempertahankan bentuk dan ukuran mikroorganisme, yang mempunyai tekanan osmotik internal tinggi. Rusaknya dinding sel (misal karena lisozim) atau inhibisi pada pembentukannya dapat menyebabkan sel menjadi lisis.

Berdasarkan hasil pengamatan, ekstrak etanol biji jintan hitam yang mempunyai rata-rata diameter zona daya hambat terbesar ditunjukan pada kontrol positif (kloramfenikol) yaitu $4,0 \mathrm{~cm}$ dan berturutturut diikuti konsentrasi perlakuan C 7500 ppm sebesar 2,4 cm, konsentrasi perlakuan B 5000 ppm sebesar 1,9 cm, konsentrasi perlakuan A 2500 ppm $1,7 \mathrm{~cm}$ dan konsentrasi terendah adalah kontrol negatif (PBS) $0 \mathrm{~cm}$. Hasil penelitian menunjukkan berbeda nyata diameter zona hambat antara konsentrasi perlakuan A 2500, perlakuan B 5000, perlakuan C $7500 \mathrm{ppm}$. Secara visual zona daya hambat yang terbentuk pada kontrol (+), konsentrasi perlakuan A $2500 \mathrm{ppm}$, perlakuan B $5000 \mathrm{ppm}$, dan perlakuan C 7500 ppm. Beberapa penelitian yang menggunakan ekstrak etanol biji jintan hitam digunakan pula untuk menghambat pertumbuhan bakteri jenis lain, seperti Shigella dysenteriae (Wadud, 2014); Escherichia coli (Asniyah, 2009). Kemampuan efek antibakteri terhadap Staphylococcus aureus juga dikemukakan oleh Masri (2015) dengan diameter daerah bebas bakteri yang berbeda minyak jintan hitam memiliki efek antibakteri yang lebih baik dari cepoperazon yang digunakan sebagai kontrol pada pengujian terhadap S. aureus.

Minyak biji jintan hitam terbukti paling efektif melawan bakteri, Ansyiah (2009), meneliti efek antimikroba jintan hitam terhadap pertumbuhan E. coli secara in vitro. Hasil dari penelitian ini menunjukkan pada konsentrasi 50\%; $75 \%$ dan $100 \%$ terbentuk zona hambatan yang berbeda nyata secara statistik. Grandiosa (2010), membuktikan bahwa ekstrak biji jintan hitam efektif menghambat pertumbuhan Aeromonas hydrophila. Berdasarkan penelitian di atas telah terbukti bahwa biji jintan hitam mempunyai aktivitas antibakterial terhadap Escherichia coli dan A. hydrophila. Potensi jintan hitam sebagai antimikroba gram negatif.

\section{KESIMPULAN}

Ekstrak etanol biji jintan hitam secara in vitro mampu menghambat pertumbuhan bakteri $V$. harveyi dan bersifat antibakterial pada konsentrasi 2500, 5000, $7500 \mathrm{ppm}$.

\section{Ucapan Terima Kasih}

Penulis menyampaikan terima kasih kepada staf pada Laboratorium Perikanan FPIK dan Laboratorium Kimia Farmasi UHO Kendari.

\section{DAFTAR PUSTAKA}

Al-Jabre, S., Al-Akloby, O.M., Al-Qurashi, A.R. 2003. Thymoquinone an Active Principle of Nigella sativa. Inhibited Aspergillus niger. Pakistan Journal Medical Research. 42 (3).

Asniyah. 2009. Efek Antimikroba Jintan Hitam (Nigella sativa) Terhadap Pertumbuhan Escherichia coli in Vitro. Jurnal Biomedika. 1(1): 25-30.

Ayaz, E., Yilmaz, H., Ozbek, H., Tas, Z., and Ozlem, O. 2007. Effect of Nigella sativa L. Oil on Rat-Peritoneum Macrophage Phagocyte Activity and Capacity. Saudi Medical Journal. 28: 16541657.

Chang, C.C, Z.R Wu, C. M Kuo, and W. Cheng. 2007. Dopamine Depresses in the Tiger Shrimp Penaeus Monodon. Fish and Shellfish Immunology, 23: 24-33.

Cheng W, Liu CH, Tsai CH, Chen JC. 2005. Molecular cloning and characterisation of a pattern recognition moleculer, lipopolysaccharide- and beta-1,3-glucan binding protein (LGBP) from the white shrimp Litopenaeus vannamei. Fish and Shellfish Immunology 18: 297-310.

Dorucu,M., Colak, S.O., Ispir, Altinterim,B., and Celayer, Y. 2009. The Effect of Black Cumin Seeds, Nigella sativa, on the Immune Response of Rainbow Trout, Oncorhynchus mykiss. Mediterranean Aquaculture Journal. 2: 27-33.

Hannan, A., Saleem, S., Chaudhary, S., and Muhammad, B. 2008. Antibacterial Activity of Nigellasativa Against Clinical Isolate of 
Methicillin Resistent Staphylococcus aureus. Journal Ayub Medical Coll Abbottabad. 20: 7274.

Hoa, T.T, D.T Hoang, and N.T Phuong. 2006. Study on disease in giant freshwater prawns (Macrobrachium rosenbergii): A Review. Department of Fisheries Biology, College of Aquaculture an Fisheries, Can Tho University 17.

Hosseinzadeh, S., Bazzaz, B.S., and Haghi, M.M. 2007. Antibacterial Activity of Total Extracts and Essential Oil of Nigella sativa L. Seeds in Mice. Journal Pharmacolgy online. 2: 429-435.

Kristianti, A.N., Aminah, N.S, Tanjung, M., Kurniadi, B. 2008. Buku Ajar Fitokimia. Laboratorium Jurusan Kimia. Surabaya.

Lo, C.F, J.L Wu, Y.S Chang, H.C Wang, J.M Tsai and G.H Kou. 2004. Molecular Characterization and Pathogenicity of White Spot Syndrome Virus. In: Leung, K.Y (ed.). Current Trends in the Study of Bacterial and Viral Fish and Shrimp Disease. World Scientific Publishing, Singapura.

Luksrejo. 2008. Jenis Penyakit Udang pada Budidaya Air Payau Kalitengah Lamongan. Jawa Timur.

Marentek, G.A., dan Manoppo, H. 2013. Evaluation of the Use of Garlic (Allium sativum) in Enhancing Non-specfic Immune Respone and Growth of Nile Tilapia (Oreochromis niloticus). Jurnal Budidaya Perairan. 1: 1-7.

Mashhadian, N.V., and Rakhshandeh, H. 2005. Antibacterial and Antifungal Effects of Nigella sativa Extracts Against $S$. aureus, $P$. aureginosa, and C. albicans. Pakistan Journal Medical Science. 21(1): 47-52.

Masri, M. Djamal, A. Putra, U.G. 2015. Uji Efek Antibakteri Minyak Jintan Hitam (Nigella sativa) Dalam Kapsul yang Dijual Bebas Selama Tahun 2012 di Kota Padang Terhadap Bakteri Staphylococcus aureus dan Escherichia coli Secara in Vitro. Pendidikan Dokter FK UNAND (Fakultas Kedokteran Universitas Andalas Padang), Bagian Mikrobiologi Klinik FK UNAND, Bagian Kimia FK UNAND. Jurnal Kesehatan Andalas. 2015; 4(2) 387-391.

Rey, A., N. Verjan, H. W. Ferguson, and C. Iregui. 2009. Patgogenesis of Aeromonas hydrophila Strainn KJ99 Infection and Its Extracelluler Product in Two Species of Fish. Veterinary Record 164, pp. 493-499.
Ridlo, A., dan Rini, P. 2009. Aplikasi Ekstrak Rumput Laut Sebagai Agen Imunostimulan Sistem Pertahanan Non-spesifik pada Udang (Litopennaeus vannamei). Ilmu Kelautan. 14: 133-137.

Sakai, M. 1999. Current Research Status of Fish Imunostimulants. Journal Aquaculture, 172(12):63-92.

Soderhall, K and L. Cerenius. 1992. Crustacean Immunity. Annual Review of Fish Disease, 2:223.

Sukenda, Sihombing, A.J., Novianti, F., dan Widanarni. 2005. Penapisan Bakteri Probiotik dan Peranannya Terhadap Infeksi Buatan Vibrio harveyi pada Udang Vaname (Litopenaeus vannamei). Jurusan Budidaya Perairan Fakultas Perikanan dan Ilmu Kelautan Institut Pertanian Bogor. Jurnal Akuakultur Indonesia. 4(2): 181187.

Suthar, M.P., Patel, P.N., Shah, T.G., and Patel, R.K. 2010. In Vitro Screening of Nigella sativa Seeds for Antifungal Activity. Journal Pharmaceutical and Applied Sciences. 1: 86-91.

Shewita, R.S., and Thaha, A.E. 2011. Effect of Dietary Supplementation of Different Levels of Black Seed (Nigella sativa L.) on Growth Performance, Immunological, Hematological and Carcass Parameters of Broiler Chicks. Journal Word Academy of Science Engineering and Technology. 53: 788-794.

Wadud, S.A. 2014. Uji Efektivitas Ekstrak Biji Jintan Hitam (Nigella sativa) Terhadap Pertumbuhan Bakteri Shigella dysenteriae. Skripsi. Fakultas Kedokteran dan Ilmu Kesehatan. Universitsas Islam Negeri Syarif Hidayatullah Jakarta. 61 hal.

Zaher, K.S., Ahmad, W.M., and Zerizer, S.N. 2008. Observation on The Biological Effects of Black Cumin Seed (Nigella sativa) and Green Tea (Camellia sinensis). Journal Global Veterinary. 2: 198-204.

Zubaidah, A., Yuhana, M., Widanarni. 2014. Penambahan Mikrokapsul Sinbiotik dengan Dosis Berbeda untuk Menanggulangi Infeksi Vibrioharveyi pada Pakan Udang Vaname (Litopenaeus vannamei). Hayati Journal of Biosciences. 